\title{
Incidence of COVID-19 Virus Transmission in Three Dental Offices: A 6-Month Retrospective Study
}

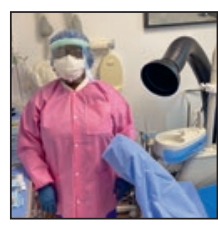

Scott H. Froum, DDS

Stuart J. Froum, DDS²

The World Health Organization (WHO) declared COVID-19 a pandemic on March 11, 2020. SARS CoV-2, the virus that causes COVID-19, has shown the ability to become aerosolized with a potential airborne route of transmission. Dentists and dental hygienists are listed as two of the occupations in a nonhospital setting with the greatest risk of contracting the SARS-CoV-2 virus, as routine dental procedures involve aerosol generation. In a statement on interim guidance, WHO recommended that all routine dental procedures be delayed until COVID-19 transmission rates decrease from community transmission to cluster cases and until the risk of transmission in a dental office can be studied and evaluated. This prospective study involves 2,810 patients treated over a 6-month period (March 15 to September 15, 2020) in three different dental offices by two dentists and three hygienists during and shortly after the height of the pandemic in New York. By utilizing screening questionnaires, performing enhanced infection control, and having appropriate personal protective equipment, these dental offices were able to record no transmission of COVID-19 to the dental healthcare workers or patients during the study. In addition, $69 \%$ of the patients treated in these dental offices were recorded as having one or more high-risk comorbidities related to COVID-19 severity. Int J Periodontics Restorative Dent 2020;40:853-859. doi: 10.11607/prd.5455

1Department of Periodontology, Stony Brook School of Dental Medicine, State University of New York, Stony Brook, New York; Private Practice, New York, New York, USA.

${ }^{2}$ Ashman Department of Periodontology and Implant Dentistry, New York University College of Dentistry, New York, New York; Private Practice, New York, New York, USA.

Correspondence to: Dr Stuart J. Froum, 17 West 54th Street, Suite 1c/d, New York, NY 10954, USA. Email: dr.froum@verizon.net

Submitted September 22, 2020; accepted September 30, 2020.

(C)2020 by Quintessence Publishing Co Inc.
The World Health Organization (WHO) declared COVID-19 a pandemic on March 11, 2020.' While this virus has affected all aspects of life and business across the globe, its potential effect on the practice of dentistry may be the most dramatic. Because Severe Acute Respiratory Syndrome (SARS) CoV-2, much like SARS CoV-1, can be aerosolized with a potential for an airborne route of transmission, dentists and dental hygienists were listed as two of the occupations in a nonhospital setting with the greatest risk of contracting the SARS-CoV-2 virus. ${ }^{2}$ Transmission of this virus via an airborne route in the dental office has been proposed, as routine dental procedures involve aerosol generation. ${ }^{3}$ In a statement on interim guidance drafted on August 3, 2020, and released on August 11, 2020, WHO recommended that all routine dental procedures be delayed until COVID-19 transmission rates decrease from community transmission to cluster cases and until a time that the risk of transmission in a dental office can be studied and evaluated. ${ }^{4}$ The purpose of this retrospective study was to determine the incidence of transmission of the SARS-CoV-2 virus in three dental offices over 6 months of the pandemic. Patient risk for COVID-19 disease severity was analyzed according to the presence of COVID-19-related 


\section{COVID-19 Screening Form}

Patient's name:

Date:

\section{PREAPPOINTMENT CHECK}

IN-OFFICE VISIT

1. Do you have a fever, or have you felt hot or feverish recently (14-21days)?

YES $\square$ NO $\square$

2. Are you having shortness of breath or other difficulties breathing?

YES $\square$ NO $\square$

3. Do you have a cough?

YES $\square$ NO $\square$

4. Any other flu-like symptoms, such as gastrointestinal upset, headache, or fatigue?

YES $\square$ NO $\square$

5. Do you currently have (or have you experienced) any of the following symptoms in the past 21 days:

Fever

Currently:

YES $\square$ NO $\square$

If fever, how did you measure it?

Fatigue (feeling tired)

Altered or loss of taste/smell

Dry cough

Trouble breathing

Shortness of breath, difficulty breathing, chest tightness

Confusion

Blueish lips or face

Chills/repeated shaking with chills

Muscle pain

Headache or sore throat

Any other flu-like symptoms

GI upset or diarrhea

YES $\square$ NO $\square$
YES $\square$ NO $\square$
YES $\square$ NO $\square$
YES $\square$ NO $\square$
YES $\square$ NO $\square$
YES $\square$ NO $\square$
YES $\square$ NO $\square$
YES $\square$ NO $\square$
YES $\square$ NO $\square$
YES $\square$ NO $\square$
YES $\square$ NO $\square$ PLEASE LIST
YES $\square$ NO $\square$

6. Have you experienced recent loss of taste or smell?

7. Are you in contact with any confirmed COVID-19-positive patients? Patients who are well but who have a sick family member at home with COVID-19 should consider postponing elective treatment.

8. Are you over age 60 ?

9. Do you have heart disease, lung disease, kidney disease, diabetes, or any autoimmune disorders?

10. Have you traveled in the past 14 days to any regions affected by COVID-19?

In the last 21 days:

YES $\square$ NO $\square$

YES $\square$ NO $\square$
YES $\square$ NO $\square$
YES $\square$ NO $\square$
YES $\square$ NO $\square$
YES $\square$ NO $\square$
YES $\square$ NO $\square$
YES $\square$ NO $\square$
YES $\square$ NO $\square$
YES $\square$ NO $\square$
YES $\square$ NO $\square$
YES $\square$ NO $\square$ PLEASE LIST
YES $\square$ NO $\square$

YES $\square$ NO $\square$

YES $\square$ NO $\square$

YES $\square$ NO $\square$

YES $\square$ NO $\square$

YES $\square$ NO $\square$

\section{POSITIVE RESPONSES TO ANY OF THESE WOULD LIKELY INDICATE A DEEPER DISCUSSION WITH THE DENTIST BEFORE PROCEEDING WITH ELECTIVE DENTAL TREATMENT.}

Fig 1 COVID questionnaire. 
comorbidities in their medical history. ${ }^{5}$ In addition, infection control protocols and specialized equipment dedicated toward airborne precautions were used in the three dental offices during the 6-month period of patient treatment.

\section{Materials and Methods}

A total of 2,810 patients were treated in three dental offices by two periodontists (S.H.F. and S.J.F.) and three hygienists during a 6-month period from March 15, 2020, to September 15, 2020. During this time, the authors treated patients for dental emergencies such as infections, painful or fractured teeth, dental or periodontal abscesses, traumatic tooth or gum injuries, complications around implants, etc. Beginning March 15, including the period of emergency care to the recommencement of routine patient care, all treatments were performed under enhanced infection control and following strict guidelines as outlined by the Centers for Disease Control and Prevention (CDC).

\section{Enhanced Infection Control Protocol}

All staff in the three offices took an online infection control class, with one staff member designated as the infection control coordinator. The infection control coordinator is responsible for the maintenance and adherence to the office standard operating procedural manual associated with infection control. Within
Fig 2 Dental health care worker in personal protective equipment.

3 days prior to their dental appointment, each patient was contacted to confirm the time and date of their appointment and to answer the COVID-19 screening questions (Fig 1), and instructions were given to wear an American Society for Testing Materials level 3 face mask to the office. If there was any evidence that the patient was positive for COVID-19 or in contact with any person who tested positive, their appointment was rescheduled. If the patient's temperature was $\geq 100.4^{\circ} \mathrm{F}$, they were told to wait outside the office for a 5-minute period, then reenter and have their temperature retaken. If the patient's temperature was $<100.4^{\circ} \mathrm{F}$ upon the first or second attempt, they were instructed to wash their hands. Patients who had a temperature $\geq 100.4^{\circ} \mathrm{F}$ upon retaking were sent home, and the appointment was rescheduled. After washing their hands, patients were again given the same list of questions previously asked on the confirmation call. If the answers were the same as during the phone call, the patients were immediately seated in a clean and disinfected operatory by a staff member dressed in full personal protective equipment (PPE).

All staff members were protected by N95 respirator masks, a full-face shield, surgical hair cover, a full-length gown, glasses with magnifying loupes, eye shields, and surgical gloves (Fig 2). Nose filters and glasses or nose shield masks with protective visors were given to patients, along with a single-use linen gown and hair cover prior to any dental treatment requiring aerosol generation. Throughout the length of this study, strict adherence to 


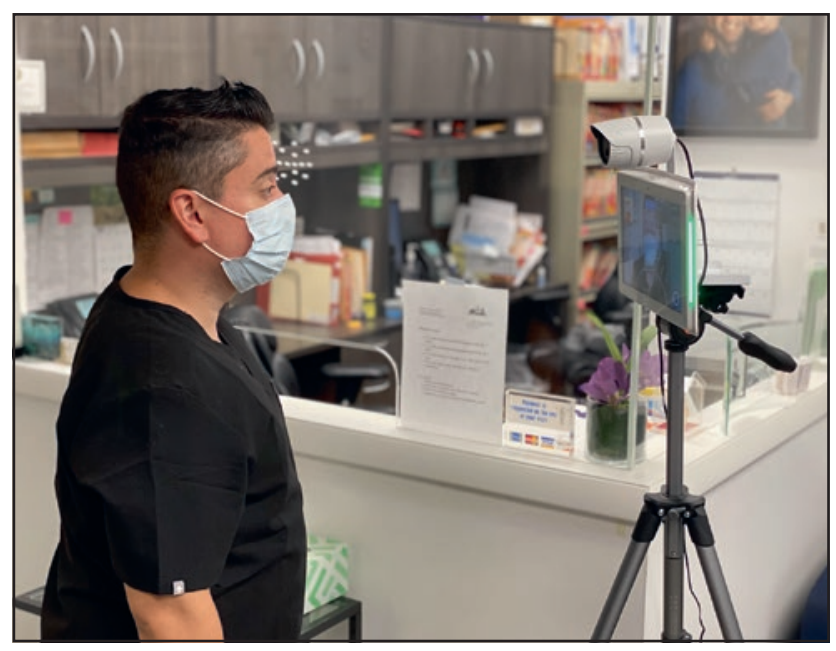

Fig 3 An infrared temperature scanner was used to check patient's temperatures.

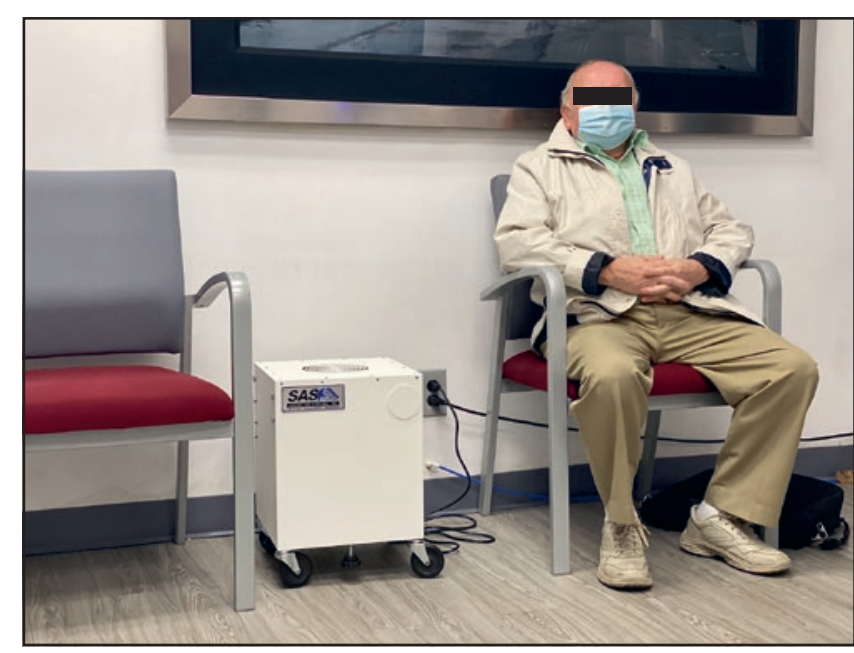

Fig 4 A high-efficiency particulate air filter (room purifier) was placed in the waiting room. both standard and enhanced infection control precautions were followed, ${ }^{6}$ including the following:

- Handheld or infrared scanners were used at the entrance to the waiting room for temperature screenings (Fig 3).

- Barrier tape and other coverings were placed throughout the treatment room, including all electronics and machines in the room.

- A 30- to 60-second rinse and gargle with $0.5 \%$ povidone iodine or $1.5 \%$ hydrogen peroxide was used by the patient prior to any dental examination or treatment.

- Low-speed saliva ejector backflow valves were used to prevent retrograde flow of contaminants into the patient's mouth during procedures.

- High-volume evacuation suctions with at least 8-mm bore sizes and low-speed saliva ejectors were used when any aerosol-generating equipment (air turbine/electric high-speed handpieces, sonic or ultrasonic cavitrons), air sprays, prophy jets, polishing instruments, or implant insertion drills were used.

- High-efficiency particulate air filters were strategically placed in all office rooms, including the waiting room (Fig 4).

- Extraoral vacuum suctions equipped with ultra-lowparticulate air filters were used during aerosol-generating procedures, positioned $\leq 18$ inches from the patient's mouth (Fig 5).

- High ultraviolet-C (UV-C) germicidal lights were placed in every treatment room (Fig 6).

- All central heating, ventilation, and air-conditioning units were modified with air-ionized filtration (air scrubbers).
- All instruments were packaged in separate bags or trays and sterilized in an autoclave.

- Following treatment, PPE (gowns, masks, hair covers, shoe covers, gloves, etc) were discarded, and each staff member involved in treatment would wash their hands with soap and water for 30 seconds or more and don new PPE. Patients used hand sanitizer and replaced their masks before they left the operatory. After, they received posttreatment instructions and scheduled their next appointment.

- Appropriate time was taken to clean and disinfect the room with Environmental Protection Agency-approved cleaning supplies directed at the coronavirus family.

- The treatment room was fogged for 2 to 3 minutes with $\mathrm{HOCl}$ at 200 ppm. 


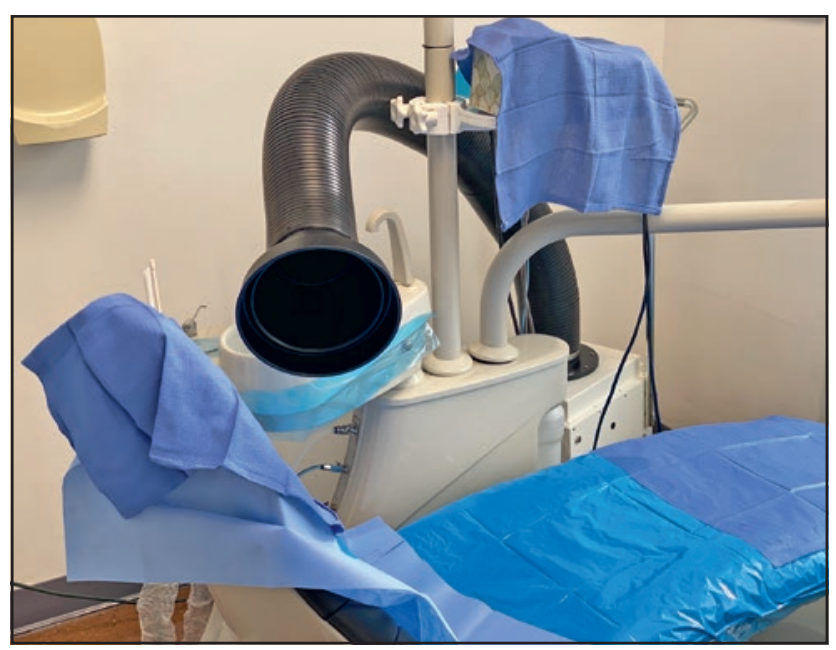

Fig 5 Extraoral ultra-low-particulate air filter.

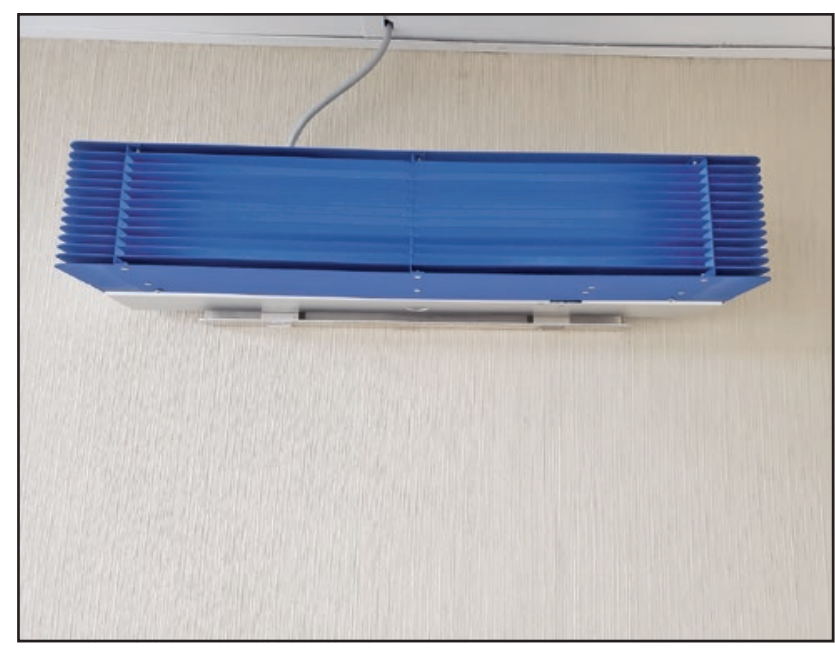

Fig 6 Ultraviolet-C light in the treatment operatory.
- Once in the operatory, if the patient had to leave for any reason (such as to use the bathroom, which was thoroughly cleansed by the staff after each patient), they would don/doff PPE and thoroughly wash hands prior to reentering the operatory.

- All patients approaching the front desk maintained $6 \mathrm{ft}$ of distance from any office staff member or other patients. Custom-made sneeze guards separated the patient and the front desk staff (Fig 7).

- The patients were given a new mask (if desired) and exited the office.

Each patient, if they did not return to the office for follow-up, was contacted 2 weeks after their appointment by email, text, or phone to document whether they experienced any COVID-19 symptoms or any other symptoms not related to

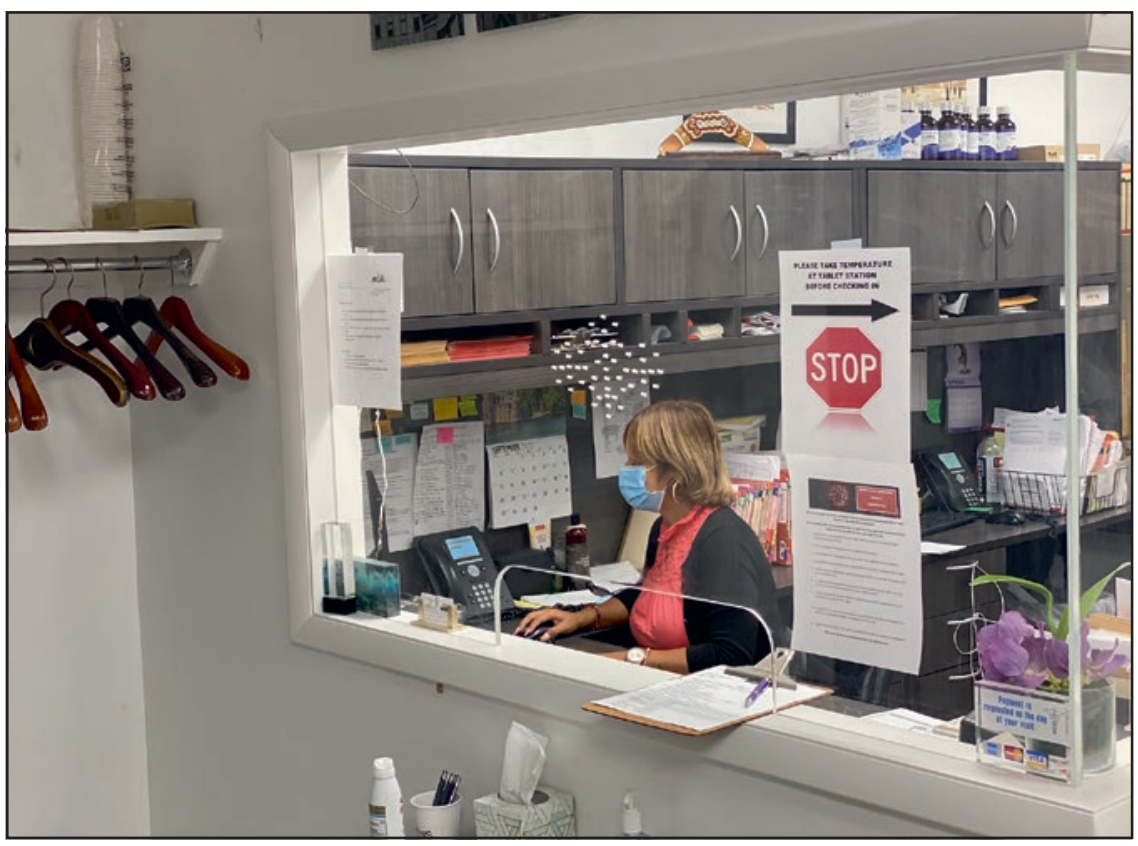

Fig 7 Sneeze guard.

normal posttreatment occurrences. These were documented in the patient's charts, and "all normal" was documented for patients with no symptoms or health problems.
Comorbidities were recorded, including age $\geq 65$ years and whether a patient had a history of diabetes, hypertension, rheumatoid arthritis, or any autoimmune disease, 
or if they were taking an immunosuppressant medication. If any of the above conditions or age categories were present, the patient was considered as having a high-risk comorbidity. The number of patients with high-risk comorbidities was recorded from the entire patient pool of 2,810 patients treated from March 15, 2020, to September 15, 2020.

\section{Results}

In three dental offices, 2,810 patients were treated by two periodontists and three hygienists during a 6-month period of time from March 15, 2020, to September 15, 2020. Of those, 1,939 (69\%) had one or more high-risk comorbidities according to the present study's criteria. Various dental treatments with aerosol-generating procedures were administered during this study period.

Once receiving the office screening questionnaire, 73 patients from the population sample called the office prior to their scheduled dental appointments to report they tested positive for COVID-19. All were under treatment by their physician or had completed treatment with their physician, and all were required to present evidence of testing negative for COVID-19 (letter from physician or negative lab results) prior to scheduling a new dental appointment. None of these patients contracted the virus in any of the three dental offices followed in this paper.
Three staff members, each working at a different office, contracted COVID-19 during the period of emergency treatment only. These staff were furloughed (not working) at the time of contracting the virus. All three staff contracted the disease from family members, had become sick, developed antibodies as shown by blood tests, and had negative polymerase chain reaction tests prior to their return to the dental office.

Control systems were put in place as directed by the CDC and Occupational Safety and Health Administration, including staff training, patient screening, strict adherence to standard operating infection protocols, distancing appointments, mask use, air purification, air filtration, ventilation, operatory sanitization with $\mathrm{HOCl}$ and UV-C light, and proper PPE use. These control systems resulted in a transmission rate of zero between office staff and patients during the 6-month period of this study, as indicated by the consistent absence of any COVID-19 symptoms of office staff and patients at 2 weeks posttreatment.

\section{Discussion}

The question of whether the SARSCoV-2 virus is capable of human transmission via aerosol particles in an airborne fashion needs to be further studied. However, to further understand why the potential for viral transmission in a dental office is exceedingly low, a distinction must be made between aerosol-generating medical procedures (AGMPs) and aerosol-generating dental procedures (AGDPs). AGMPs are those procedures that agitate the airway (eg, tracheal or bronchial intubation) and may induce the patient to cough forcibly, thereby releasing aerosols filled with a large viral infectious dose. AGMPs used for inductive procedures present the highest risk of aerosol transmission.7 AGDPs, on the other hand, are procedures that produce aerosols during instrument vibration, rotation, and air compression when contacting oral fluid. Oral secretions and nasal fluid usually have less viral concentrations than chest secretions. In addition, unlike in hospital settings, AGDPs are often accompanied by high-volume evacuation and/or other filtration devices. These suction techniques lower an already low potential for transmission in the dental environment. That being said, control systems using ventilation, intra- and extraoral suctions, and full PPE still need to be employed, as the dental health care worker can encounter secretions with large viral load via a cough or sneeze. ${ }^{8}$

\section{Conclusions}

During the height of the COVID-19 pandemic in New York, no dentists, staff member, or treated patient contracted SARS-CoV-2 in any of the three followed dental offices during the 6-month working period. Of the patient population, $69 \%$ had high-risk comorbidities, showing that dental care can be administered safely even in high-risk patients. 


\section{Acknowledgments}

The authors declare no conflicts of interest.

\section{References}

1. World Health Organization. WHO DirectorGeneral's opening remarks at the media briefing on COVID-19, 11 March 2020. https://www.who.int/dg/speeches/ detail/who-director-general-s-openingremarks-at-the-media-briefing-onCOVID-19---11-March-2020. Accessed 28 September 2020.
2. Lu M. The front line: Visualizing the occupation with the highest COVID-19 risk. https://www.visualcapitalist.com/thefront-line-visualizing-the-occupationswith-the-highest-covid-19-risk/. Visual Capitalist. Accessed 28 September 2020.

3. Peng $X, X u X$, Li Y, Cheng L, Zhou X, Ren B. Transmission routes of $2019-n C o V$ and controls in dental practice. Int $\mathrm{J}$ Oral Sci 2020;12:9.

4. World Health Organization. Considerations for the provision of essential oral health services in the context of COVID19: Interim guidance, 3 August 2020. https://apps.who.int/iris/bitstream/ handle/10665/333625/WHO-2019nCoV-Oral_health-2020.1-eng.pdf. Accessed 28 September 2020.
5. Richardson S, Hirsch JS, Narasimhan M, et al. Presenting characteristics, comorbidities, and outcomes among 5,700 patients hospitalized with COVID-19 in the New York City area. JAMA 2020; 323:2052-2059.

6. Harte JA. Standard and transmissionbased precautions: An update for dentistry. J Am Dent Assoc 2020;141: 572-581.

7. Wölfel R, Corman VM, Guggemos W, et al. Virological assessment of hospitalized patients with COVID-2019. Nature 2020;581:465-469.

8. Chanpong B, Tang M, Rosenczweig A, Lok $P$, Tang R. Aerosol-generating procedures and simulated cough in dental anesthesia. Anesth Prog 2020;67:127134. 